\title{
SELLO AUTORIAL: EL CASO SPIELBERGIANO COMO EJEMPLO DEFINITORIO DE ESTILEMA
}

\author{
David Caldevilla Domínguez Universidad Complutense (España)
}

\section{Introducción}

Este artículo tiene pretende ahondar en el concepto de sello autorial o estilema, focalizado en Steven Spielberg como director. A partir de ese punto estableceremos un modelo de análisis para diseccionar la obra del director, con particular atención a las películas de la saga "Indiana Jones". Tomándola como referencia, procuraremos probar que Focalizando sobre ella intentaremos demostrar que existe un sello autorial propio Spielberg; visible en todos sus trabajos, inclusive las más personales de sus películas. Dado el fuerte componente de análisis textual de lo cinematográfico que requiere esta investigación, resulta igualmente importante de cara a una labor completa, visionar las cintas en las que el autor analizado ha intervenido como productor o director; puesto que pretendemos diseccionar pormenorizadamente cada detalle ateñente a la creatividad autorial que pueda observarse en ellas. Semejante análisis tendría que contemplar para sus conclusiones, todas las consideraciones icónicas y sonoras pertinentes al medio de manifestación artística y creativa en el que se desenvuelve Spielberg. Dicho análisis textual y audiovisual debería ayudarnos a segregar los elementos primarios relevantes para determinar las marcas de estilo. Lo que a su vez nos permitirá aislar aquellos que constituyen el estilema particular del director norteamericano. Todo ello centrará los objetivos de nuestra investigación.

\section{Metodología}

A la hora de diseñar un modelo de análisis para la obra de Steven Spielberg hemos planteado un esquema que abarque todos los elementos constitutivos de "lo narrativo audiovisual". Inicialmente, nos basaremos en los dos planos básicos de análisis narratológico: historias (significados) y discursos (significantes).

El método científico (en puridad es definido por Mario Bunge como "procedimiento regular, explícito y repetible para lograr algo, sea material, sea conceptual") ha sido considerado tradicionalmente como base del saber de las ciencias denominadas puras o que tenían magnitudes extensivas como objetos de estudio. Las ciencias humanas, más creativas y no supeditadas a la esclavitud del Sistema Métrico Decimal, al poseer naturaleza intensiva su objeto de análisis las más de las veces, adolecían de esa consideración que las elevara al altar de ciencia. Afortunadamente este momento del pensamiento ha pasado legándonos una rica visión en lo referente a metodologías aplicables a nuestra rama del conocimiento humano ${ }^{1}$. Bien es cierto

1 Siguiendo la opinión de Ferrater Mora en su artículo para el Diccionario de filosofía de la Editorial Suramericana de Buenos Aires en su edición de 1979, convenimos con él en considerar que "en el llamado saber vulgar hay ya, casi siempre de modo implícito, un método, pero éste último cobra 
que su generalidad, debida a su naturaleza universalizable, pues el método ha de ser herramienta en múltiples batallas, hace que sus postulados nos obliguen a instrumentalizar ad hoc su naturaleza analítica. No quiero dejar pasar esta oportunidad para plantear la taxonomía de Bunge, el feraz profesor neopositivista argentino residente en Canadá, como Vía Apia del sistema de trabajo planteado.

Así, para Mario Bunge ${ }^{2}$ los pasos que seguir para llegar a la verdad sobre el conocimiento son nueve:

1. Descubrimiento del problema.

2. Planteamiento preciso del problema.

3. Búsqueda de conocimientos o instrumentos relevantes.

4. Tentativa de solución del problema con ayuda de los medios identificados.

5. Invención de nuevas ideas.

6. Obtención de la solución del problema.

7. Investigación de las consecuencias de la solución obtenida.

8. Puesta a punto o contrastación de la solución.

9. Corrección de las hipótesis, teorías, procedimientos o datos empleados en la obtención de la solución incorrecta.

En nuestro caso podemos subsumir los nueve postulados en cinco fases muy claramente diferenciadas:

1. Delimitación del objeto que se pretende investigar con especial atención a los elementos contextualizadores.

2. Recolección de datos pertinentes tras una observación de los fenómenos bajo estudio.

3. Estructuración, jerarquización, análisis y evaluación de los datos tratados.

4. Emisión de conclusiones generales o particulares en la investigación.

5. Contrastación experimental si procede de las conclusiones elevadas a definitivas, con su correspondiente afinamiento de proceso y retroalimentación si las conclusiones iniciales y los datos de la contrastación no fueran acordes.

Estos pasos se concretan en nuestro objeto de estudio, la obra de Spielberg, en varios aspectos que enumeramos:

Penetrar en la estructura interna de los relatos de Steven Spielberg.

Aplicar el modelo concreto a la Trilogía de Indiana Jones en especial.

\begin{tabular}{llll}
\hline importancia enicamente científico". & saber
\end{tabular}


Definidos los aspectos de la obra de Spielberg, se remarcarán los rasgos invariantes en cada uno de los apartados del modelo analítico.

Estos rasgos invariantes de estilo, vendrán dados por la aplicación de un esquema general que recoge completamente todos los aspectos por estudiar en una obra televisiva y cinematográfica de tipo narrativo, sin que esto represente óbice para ir añadiendo en forma de sub-esquemas derivados, aquéllos que considere necesarios para completar este esquema macro.

Aplicación de un método basado en los aspectos psicoanalíticos sobre el autor y el espectador. Este modelo está planteado desde los estudios de Sigmund Freud y Jacques Lacan especialmente y se centra en el concepto de identificación.

La metodología que emplearemos será la de aplicación de los conocimientos que definen analíticamente una obra audiovisual narrativa, a la obra conjunta de Spielberg y más en concreto, a la Trilogía que forma un subgrupo característico dentro de su obra total.

En concreto, la aproximación al planteamiento metodológico queda establecida desde la misma fuente generadora de sucesos: la obra de Spielberg con lo que nuestros presupuestos se concretizan en sus líneas maestras conforme a su naturaleza.

El modelo de análisis se deriva inicialmente del esquema planteado en las páginas sucesivas, con sus factores y descriptores que serán más ampliamente desarrollados en la aplicación concreta. Se emplearán criterios de cuantificación y de calidad ya que el valor de los diversos elementos viene dado no sólo por su número sino por su intensidad y cualidad, criterios éstos que mucho tienen que ver con la creatividad.

Tendremos la consiguiente formulación de objetivos ya expuesta, sostenida por los pilares de subrayado yacentes en su obra en un primer momento pero no debemos pasar por alto que existen otras directrices investigadoras de lo audiovisual cinematográfico que han de ser abandonadas, no por no pertinentes en alguno de sus aspectos, sino porque no hallaremos en ellas valores de ese subrayado que permitirá crear puntos de parentesco entre las hipótesis iniciales y las conclusiones que puedan ser derivadas de ellas por tocar temas que no consideramos nucleares. Así, en la fase de recogida de datos, nuestra atención prioritaria se focalizará en los elementos de articulación que se incardinen en nuestro esquema o prontuario de intenciones y en la siguiente fase de ordenación, análisis y valoración (pese a la carga subjetiva que conlleva y que por inevitable soslayamos) recurriremos a mecanismos de comparación y redundancia sobre base sintagmática.

La división del trabajo se llevará a cabo mediante la focalización de los "momentos" de su obra y las características de su producción y realización bajo este perfil de corte genérico que exponemos, siguiendo los trabajos de Seymour Chatman en su Historia y Discurso.

El método que acabamos de plantear posee un componente sólidamente basado en una analítica textual-audiovisual que pretende discernir los aspectos de índole temática y formal de la obra de cualquier cineasta, en este caso Steven Spielberg.

En nuestro caso nos basaremos en la aplicación concreta de varias teorías generales, a las que se añade, claro está, esa enciclopedia de cultura cinematográfica que todo autor (iy lector!) posee a la hora de afrontar el relato audiovisual y que marca sus influencias. Por lo tanto no sea de extrañar que ciertas teorías y propuestas de análisis sean atribuidas a las sugerencias que desde ciertos 
autores o escuelas de pensamiento se han formulado al respecto y otras sean debidas al resultado de hacer pasar la obra de Spielberg por el tamiz de los conocimientos personales propios del saber audiovisual.

Consideremos que la esencia del presente método consiste en plantear los aspectos teóricos formales según cada autor o corriente de pensamiento, incluyendo los subesquemas que se propongan por su parte y aplicar dichos bisturíes analíticos a la obra de Spielberg de manera que cada consideración teórica se haya focalizado sobre nuestro objeto de estudio: la obra de Steven Spielberg tanto en cine como en televisión en lo referente a la realización y a la producción. Las conclusiones se irán desgranando una a una en cada apartado de manera que al final, la recopilación de las mismas y su visionado en conjunto (el todo va más allá de la simple suma aritmética de las partes, tal y como nos recuerda la teoría de la Gestalt) nos permitan corroborar o refutar las hipótesis iniciales.

El criterio general de aplicación será el de concatenación espaciotemporal de nexo causal entre los elementos que conformen unidades narrativas remarcadas y remarcables.

Para concluir no quiero dejar pasar la ocasión de citar a Raymond Bellour en su "Á bâtons rompus" ("Sin orden ni concierto") en Théorie du film ${ }^{3}$, y en su L' analyse $d u$ film $^{4}$ ya que delimitan las posibilidades reales exigibles a un corpus analítico:

"La operación de análisis circunscribe aquello que trata como el efecto de proyección de una realidad de la que sólo puede indicar los efectos como un punto de fuga; en ese sentido encierra siempre los efectos de un volumen que se desarrolla. Puesto que para el análisis se trata siempre de ser verdadero, en ese sentido desarrolla su propia virtualidad como no conseguida en el texto y, con ese derecho, da siempre cuenta de una relación entre el espectador y la película, más que de una reducción sin orden ni concierto." ${ }^{3}$

y

"La imagen en movimiento es propiamente incitable, puesto que el texto escrito no puede restituir lo que sólo el aparato de proyección puede dar: un movimiento, cuya ilusión garantiza la realidad. Las reproducciones, incluso de muchos fotogramas, sólo manifiestan una especie de impotencia radical para asumir la textualidad de la película. Sin embargo, son esenciales. Representan un equivalente, ordenado cada vez según

3

Raymond Bellour (1980): "Á bâtons rompus", en Theorie du film. Obra colectiva. Editorial Albatros. París.

4

Raymond Bellour (1979): L’analyse du film. Editorial Albatros. París. 
las necesidades de la lectura, de lo que es en una mesa de montaje el paro de imagen, que tiene la función perfectamente contradictoria de abrir la textualidad de la película en el instante mismo en que interrumpen su despliegue. Se parece en cierto modo a lo que uno hace cuando se para a releer y a reflexionar sobre la frase de un libro. Pero lo que se detiene no es el movimiento. Se suspende la continuidad, se fragmenta el sentido; no se atenta de la misma manera a la especificidad material de un medio de expresión. .."

\section{Marco de actuación analítico}

Aseveraremos, desde la teoría estructuralista, que:

Toda narración posee dos partes:

- Una historia, es decir, el puro contenido o cadena de sucesos acciones y acontecimientos, a lo que se añaden los existentes o personajes y escenario. Y...

- Un discurso, sea la expresión, los medios y estrategias creativas a través de los cuales se comunica el contenido.

La metodología que se empleará es la de pasar por el tamiz del esquema anterior y los que de él derivaremos en gradiente de complejidad, toda la obra de Steven Spielberg y cotejar las hipótesis que antes se han planteado para emitir unas conclusiones que afectan a todos los ámbitos de la creación narrativa cinematográfica y televisiva. En especial se analizarán con criterios de focalización insistente, las tres películas correspondientes a la saga de Henry Jones Hijo, más conocido como Indiana Jones ya que poseen rasgos de pertinencia a un orden propio dentro de la megaestructura de las realizaciones de Steven Spielberg.

Estos componentes de orden se deben a que la Trilogía cumple los tres preceptos que ha de poseer esencialmente toda estructura, del tipo que sea, para ser considerada como tal: integridad, transformación y autorregulación. Y además, al estar formada por tres unidades autónomas podemos añadir el concepto de autorreferencialidad y coherencia.

Así pues, someteremos a juicio, en primer lugar, la realidad cinematográfica para particularizar sobre la obra de un gran director dentro de la historia del cine, que cuenta por éxitos todas sus realizaciones para la gran pantalla y que, además, posee uno de los dones más preciados: su juventud, que puede hacer que su pasado sea sólo una efímera promesa de lo que es hoy aún para todos sus espectadores incondicionales, entre los que me encuentro, el presagio de un áureo porvenir, que ójala se nos presente como un futuro -"ese país desconocido" de la saga de "Star Trek"- especialmente brillante y didáctico para las generaciones venideras.

Pueden, por lo tanto, pasarse estas páginas como si de un Albo lapillo notare diem, permitiéndoseme ese parangón, se tratara.

\subsection{Conceptos narrativos}


La teoría narrativa no aparece como un todo finito completamente cerrado, sino que se nos presenta como algo por acabar. Se trata de estudiar el fenómeno audiovisual como parte de la comunicación.

La narrativa está compuesta por la expresión o discurso (significante) y el contenido o historia (significado). El campo de la expresión dentro de la narración se basa en la dicotomía formada por la historia que es el contenido de la expresión narrativa, y discurso que es la forma de dicha expresión.

Los significados son tres: suceso, personaje y detalle escénico. Los significantes son aquellos elementos en el enunciado narrativo en cualquier medio que representan uno de estos tres.

Los componentes del plano de la expresión hacen referencia a significados componentes del plano de contenido. La forma del contenido es la estructura de cada lengua. La historia es el contenido de la expresión narrativa, mientras que el discurso es la forma de esta expresión.

\subsection{El autor sus funciones y recursos.}

Al narrador literario (aquél que cuenta la historia) le están permitidas ciertas licencias y entre ellas la más paradójica: mentir.

La importancia de Spielberg radica en la de su papel en la siguiente ecuación: si el relato está constituido por el discurso del narrador (en sí mismo polifónico) y el discurso de los personajes citados por el narrador con todas sus correspondientes cualidades polifónicas tan variadas, la ubicación del autor (director de la película) queda fuera de la comunicación ficticia, pero no es una ausente: es quien cita y usa el discurso.

En la estructura del acto narrativo ficticio se comunican realmente narrador y narratario. En cuanto al narrador debemos distinguir el relato en primera persona, en el cual el narrador es personaje o testigo y el relato en tercera persona, en el cual el narrador cuenta desde fuera, sin participar en el mundo narrado, es decir, sin mostrarse gramaticalmente como narrador.

En la narración homodiegética el narrador deja en el texto señales de su personalidad aunque sea pretendidamente un cronista. En la narración heterodiegética el autor, al no constituirse como emisor por medio de la enunciación, carece de personalidad, de sustancia psicológica, es decir, hablamos del narrador impersonal por oposición al personal, que dice "yo".

La voz narrativa da pistas que permiten reconstruir a esa persona dotada de sustancia psicológica, de emociones, sensaciones, ideas y cosmovisión, es decir, que esas enunciaciones que vislumbramos tienen su origen en una persona, fácil o difícilmente definible, según su deseo expreso o no de decir cosas sobre sí misma.

\subsection{El autor implícito}

A cada tipo de narración, cada tipo de propiedades. A un "él" narrador se le permite la omnisciencia y ubicuidad en el relato, cosa que a un "yo" le está vetada por irrealismo palpable.

El autor implícito es el autor tal y como se muestra, se construye o se denuncia en su obra. Es lícito considerar que el autor es, en resumen, un conjunto de elecciones - de temas, de técnicas, de puntos de vista - que hacen de su obra lo que es. A la 
hora de analizar al autor desde los más variados puntos de vista, recordaremos que éste se nos manifiesta en su implicación mediante las elecciones audiovisuales y técnicas del estilo, en la ideología que sustenta, los temas abordados y la resolución de conflictos.

El espectador percibe al autor implícito en la medida en que es capaz de desdoblarse y adoptar el papel de espectador y narratario del narrador, y es frecuentemente utilizado en las comedias como factor desencadenante de contradicciones entre visto / oído por quien cuenta una historia (la describe) y se nos muestra la verdadera versión de lo que pasa.

El discurso del autor funcionaría como un texto subyacente, que puede emerger o no y que recibe distinta atención, importancia e interpretaciones en las distintas lecturas históricas de la obra. Claro es que el texto del autor emerge cuando el narrador lo cita. El punto de vista del autor se enfrenta a la palabra rectora del narrador.

El autor implícito es un emisor - hablante del texto, pero un emisor citado o mejor suscitado por el narrador que es ficticio ya que ha sido creado por el autor de carne y hueso.

\subsubsection{Los realizadores}

Spielberg deja su impronta en todas y cada una de las realizaciones que hace, bien sean de carácter puramente comercial como la saga de Indiana Jones, "Hook, el capitán Garfio", "Parque Jurásico" o "Mundo Perdido", bien sean de carácter intelectual para conseguir sus tan ansiados Óscares como "La lista de Schindler", "El color púrpura", "El imperio del sol" o "Salvar al soldado Ryan". Podemos ir deduciendo, tras el visionado de las películas que componen la totalidad de la obra de Spielberg que éste plantea su cosmovisión en ellas, pues la aventura no se detiene ante nada y sus creencias religiosas se reflejan vívidamente, de manera que podemos declarar, sin miedo al error, que nos encontramos ante un judío con leve conciencia de etnia aunque real.

Este hecho de impronta personal en el enfoque (elementos discursivos en la acción pura y dura que sirve de base de la Trilogía) de la historia y de significados en relieve sobre las variadas posibilidades ofrecidas (la discriminación y la xenofobia religiosas y étnicas) marcan a un director comprometido y creador.

El autor es autor en cuanto crea, es decir, no se puede ser director - autor - creador sin ser guionista, figurinista, productor, iluminador, sastre y hasta decorador. Las responsabilidades del director - autor - creador se plasman en el correcto funcionamiento de la maquinaria y engranajes que configuran el total de los elementos intervinientes en la obra audiovisual.

\subsubsection{Binomio director-guionista}

Los temas que trata Spielberg versan sobre extraterrestres que contactan con nosotros 0 aventuras inverosímiles plagadas de riesgos que son sorteados por el héroe uno tras otro sin perder el sombrero, o unas terroríficas fauces que amenazan nuestras vacaciones. Son héroes en su más puro sentido griego, seres a los que les suceden cosas por encima de sus posibilidades humanas y salen indemnes de su encuentro con esas fuerzas que los rodean y amenazan, es decir, superan las pruebas a las que son sometidos. 


\section{4. ¿Qué es la narrativa audiovisual?}

La palabra narrativa, como concepto, hace referencia a la sucesión de cosas contadas (relatadas) sea cual fuere la naturaleza del medio empleado para ello. Implica una sucesión (la simultaneidad de acontecimientos ha de plasmarse linealmente, pues la lectura humana así lo requiere), es decir, unos "momentos" anteriores y otros posteriores a uno dado que tomamos como punto de referencia. Se apoya en los lenguajes expresivos.

Entendemos por audiovisual aquella manifestación artístico - técnica de la creatividad humana compuesta por elementos auditivos y visuales. El término cine, en su sentido tradicional, abarca una serie de fenómenos distintos, cada uno de los cuales requiere un enfoque teórico específico, desde los económicos de la producción, a los psicológicos que estudian el comportamiento del mercado general o mercados específicos o locales (espectadores que pagan en taquilla por ejemplo) pasando por los estéticos más tradicionales.

\subsection{1. ¿Dónde hallamos la verdadera y esencial naturaleza substantiva del cine?}

La teoría descriptiva es aquella destinada a crear cánones y gramáticas sobre lo correcto (o normativo) y lo incorrecto. Enunciaría reglas por lo tanto, que permitieran realizar películas. El usar esas reglas de una forma distinta a la enunciada sería crear un tipo distinto de cine, evolucionar y cambiar.

La estética del cine presenta dos aspectos: la vertiente general (efecto estético propio del cine) y la específica, centrada en el análisis de obras particulares, es decir la crítica tal y como la conocemos.

\subsubsection{Cine narrativo y no narrativo}

El cine es un compendio de elementos técnicos que han tomado del campo de la realización su particular jerga para darle forma a sus contenidos, que muchas veces han sido tenidos como transmisores de ideologías, conocimientos o, en general, información bajo cualquier aspecto genérico o formal. El espectador pone de su parte, asimismo, una serie de elementos a priori que permiten la correcta descodificación para su forma de entender (espacio y tiempo) que confieren un ritmo y temporalidad aún en las realizaciones cuya pretensión sea la de borrar estos configurantes en su representación.

\subsection{El cine: características de su narrativa}

Toda figuración o representación (y el cine lo es), lleva a la narración, pero, eso sí, siendo posible establecer un modelo propio de lo narrativo cinematográfico, diferente de lo teatral o novelesco, por poner un ejemplo.

En todo relato, la manera de seleccionar, agrupar, dosificar y emitir los contenidos que pretendemos transmitir es determinante. En el caso del cine la manera de narrar es tan importante que puede marcar el sentido de toda la narración o historia; es decir, el suyo específico del cine hay que buscarlo no en la historia, sino en el 
discurso tal y como hemos visto ya, por lo que no es aventurado afirmar que "en el cómo, vemos qué se cuenta".

Hay dos niveles en los que se desenvuelve el relato cinematográfico: A) el lingüístico, temático o de argumento y B) el retórico, semiótico o metalingüístico. Lingüística y semiótica se unen en el cine para formar el relato cinematográfico. Esta relación será tratada de distinta forma por cada director creando así películas con su propio sello personal en el que priman los aspectos lingüísticos o los semióticos dependiendo de su forma de hacer y ser y de su concepción del cine y del relato. De su mezcla puntual y habitual por iteraciones derivaremos ya una fuente de información importante sobre la naturaleza de dicho estilema o sello personal.

En la linealidad de la plasmación de una historia con referente directo sobre nuestra experiencia de lo que llamamos realidad objetiva, verdadero fin del cine convencional, encontraremos el ritmo del mismo. Es el propio de todo desarrollo narrativo. El ritmo sólo puede ser juzgado en razón de su relación con la obra misma en la que se pretende estudiar o analizar. No es un término absoluto, aunque bien es cierto que no puede tener el mismo ritmo una película de corte psicológico que una de aventuras desbocadas, y esto lo tiene muy claro Steven Spielberg.

\subsubsection{Cine y narración}

Había numerosas razones para que cine y narración se encontraran, las más importantes afectan a la materia de la propia expresión cinematográfica (imagen móvil figurativa e imagen en movimiento) y a la búsqueda de una legitimidad.

Nos interesa en la presente tesis el cine narrativo, el cine cuyo fin es contar una historia (más o menos verosímil), que es el que Spielberg realiza. Aumont afirma, y estamos de acuerdo con él, que toda película es película de ficción. El cine de ficción es doblemente irreal, por lo que representa (acción irreal y decorados falsos) y por la manera en que lo representa (imágenes de actores o de objetos).

Concluyamos que toda historia es homeostática: se va a limitar a referir la reducción de un desorden, devolverlo a su lugar. La instancia narrativa (historia, relato y narración) tiene una libertad restringida para su organización interna y la sucesión de secuencias o programas es, por el contrario, libre de escoger la manera en que se han de llevar las funciones o fijar los atributos y las características de los personajes.

\subsubsection{Cine y lenguaje}

El cine, como arte que es, necesita estar dotado de un lenguaje específico y propio, el lenguaje cinematográfico. Todos los teóricos han admitido que el lenguaje cinematográfico es muy diferente al lenguaje real, y ya los primeros teóricos del cine mencionan la expresión de lenguaje cinematográfico como propio.

Este nuevo lenguaje, el cinematográfico, tiene un carácter esencial (o sea, basado en esencias) y en ello reside su universalidad, lo cual permite evitar el obstáculo de la diversidad de lenguas nacionales. Podemos afirmar que el cine y el lenguaje cinematográfico realizan el gran sueño de un esperanto visual.

El fin de la gramática cinematográfica es permitir la adquisición de un "buen estilo cinematográfico", o bien de "estilo armonioso", gracias al conocimiento de las leyes fundamentales y de unas reglas inmutables que rigen la construcción de una película. Y sobre la base del conocimiento de estas reglas, cada director o realizador podrá optar por seguirlas y adoptarlas o no, creando así su propio "efecto estilístico" 
(Spielberg crea su estilema de autor siguiendo las reglas que él considera acertadas y entendiendo de una forma singular el lenguaje cinematográfico y aplicándolo de la forma que él considera correcta).

Seguimos a Metz en su afirmación de que el cine se postula como un lenguaje, pero se estudia gramaticalmente como una lengua. El cine es, por tanto, "como un lenguaje".

El lenguaje cinematográfico sonoro va a combinar ciertas materias diferentes: imágenes fotográficas colocadas en serie, el sonido articulado-fónico, el musical y el analógico (ruido). Únicamente las imágenes con sensación de movimiento son específicas del lenguaje cinematográfico. De ahí la matriz de su esencia.

Por decirlo en otras palabras: sobre la base de una concepción clásica y un perfecto conocimiento de lo que es el lenguaje cinematográfico universal, Spielberg desarrolla lo que es para él el cine y su forma de entenderlo, creando así acentos y silencios, es decir, su propio estilema personal.

\subsection{Historia y narración}

La narrativa audiovisual está formada por dos conceptos básicos: la historia (lo que ocurre) y la narración (relato, discurso, etc. . . es, en fin, el modo en que es contada la historia).

El "arte" de la narración puede, por sí solo, dar cierto interés a una historia carente de sorpresas, al igual que una mala narración puede estropear el interés por una buena historia, algo que todos hemos podido comprobar en el visionado de ciertas películas.

Hemos de tratar insoslayablemente el concepto de historia narrativa en sus tres aspectos principales: la historia narrativa como acción, como texto y como relato. Dolezel separa el concepto de historia tanto del espacio como del tiempo y lo hace coincidir con la acción. J. García Jiménez define al texto narrativo como: "aquel conjunto finito $y$ estructurado de signos lingüísticos en el que una instancia enunciadora cuenta una historia". Finalmente el relato es el significado de la historia contada, es el significado del texto narrativo y equivale al concepto de historia relatada.

¿Qué es, por tanto, la historia narrativa? "Aquello que es contado en unos medios determinados, de un modo determinado y con un fin determinado de acuerdo siempre con unas reglas de codificación y descodificación a las que llamaremos gramática"5.

\section{El sello autorial en la narrativa cinematográfica}

El sello autorial: este es quizá el elemento más importante a la hora de poder definir nuestras ideas desarrolladas en la presente tesis. Varios autores han recurrido a esta expresión sin llegar, desde mi punto de vista, a completarla de contenidos de

GARCÍA JIMÉNEZ, Jesús (1993): Narrativa audiovisual. Editorial Cátedra. Madrid. 
forma suficiente y necesaria para elevarla de mera expresión literaria a categoría formal.

Definimos sello autorial como la forma particular, personal e intransferible, aunque sí imitable, que un creador tiene de plasmar consciente 0 inconscientemente su aportación personal en todos $y$ cada uno de los elementos conformantes de ese todo que llamamos obra y que como tal nos permite tomarla como objeto de nuestro estudio.

En el caso del cine nos referimos a la más interesante para nosotros: la del director / creador. Aplicada toda esta impedimenta cultural en nuestro hic et nunc, a Steven Spielberg por su calidad de tal.

\section{Relaciones entre las instancias narrativas}

Distinguiremos entre:

Autor - narrador: Se trata de reivindicar la figura del artista, entendido como creador, que no artesano, en la industria del cine. Aquí se incardinan los elementos que dan carta de naturaleza al concepto del sello propio y personal de cada autor porque cada persona tiene una personalidad que desarrolla en su labor, destacando o anulando algunos aspectos o puntos conformantes. Este trabajo no es obra, las más de las veces, de una sola persona, pero indiscutiblemente los elementos que le son ofrecidos por otros intervinientes en la obra, son definitivamente seleccionados y mediatizados por él.

Instancia narrativa: Es el lugar abstracto donde se elaboran las elecciones para la conducción del relato y la historia, donde se desarrollan los códigos y se definen los parámetros de producción del relato audiovisual. La instancia narrativa "real" es lo que "queda fuera del cuadro" en el cine narrativo clásico.

Personaje / narrador: La instancia narrativa "ficticia" es interna y está explícitamente asumida por uno 0 varios personajes en cada momento 0 alternativamente.

El sello autorial no se incardina en la búsqueda de nuevas fórmulas partiendo de la nada, o innovando desde los más profundos cimientos, sino que hay que buscarlo en la apuesta estética personal partiendo de opciones mayoritariamente ya establecidas para encontrar nuevos sentidos por oposición, adición, supresión, multiplicación o mediante cualquier otra naturaleza de combinación posible con lo que se crea una manera de hacer las cosas. Si se recurre de manera rítmica a ciertas cadencias o elementos, se acaba por marcar una huella en el espectador, a través de sus obras, por la que éste reconoce la autoría. Autoría, por otra parte, que puede crear escuela y seguidores.

Todos los directores de cine poseen una pauta clara en el tratamiento de los géneros cinematográficos. Si ésta innova al incluir elementos novedosos en uso o en naturaleza estaremos ante un sello autorial, si no, ante un artesano correcto o un mal director.

\subsection{Los códigos narrativos}


El narrador real no es el autor porque su función no podría confundirse con su propia persona. El de narrador es siempre papel ficticio, puesto que actúa como si la historia fuera anterior a su relato (cuando en la realidad es el relato el que la construye) y como si él mismo y su relato fueran neutros ante la verdad de la historia. Tampoco la función del narrador es la de expresar sus preocupaciones esenciales, sino la de seleccionar, por la conducción de su relato, entre una serie de procedimientos de los que no es necesariamente el creador, pero sí a menudo el usuario.

Consideraremos que el narrador es el realizador, en tanto que es quien recoge, selecciona, escoge, ordena y dispone un tipo de encadenamiento narrativo, un tipo de planificación, un tipo de montaje por oposición a otras variadas y múltiples posibilidades que serían tomadas desde el punto de vista formal / gramatical como correctas, pero, sin embargo, para él no son las mejores o más adecuadas.

El concepto de narrador no excluye, ni lo pretende, la idea de producción e invención: el narrador produce por completo a la vez una historia y un relato a la par que inventa ciertos procedimientos del relato o ciertas construcciones de la intriga. Conviene recordar el valor semántico del silencio o la ausencia de ciertos elementos o rasgos.

Siguiendo a M. Marie, la instancia narrativa real es lo que, de común, queda fuera de cuadro. El estilema de autor adopta aquí su punto metatextual, al aparecer físicamente él mismo en su obra marcándola indeleblemente con su presencia. La instancia narrativa ficticia debe ser considerada como interna a la historia y está asumida por uno o varios personajes.

A. Bergala y M. Vernet definen la historia o diégesis como el significado o el contenido narrativo (la idea de historia no presupone la agitación). Así la coherencia de ésta es lo que nos la muestra como autónoma o independiente del relato que la forma y conforma. Aparece la historia dotada de existencia propia que la constituye como simulacro del mundo real. El concepto actualizado de diégesis nos lleva a considerar a la historia como un cuasi mundo, como un universo ficticio cuyos elementos ordenados según las leyes de la lógica humana y su naturaleza comprehensiva, forman un todo. Mencionaremos el concepto de universo diegético. Éste comprende la serie de acciones, su supuesto marco y el ambiente de sentimientos y motivaciones en la que se produce (en la obra de Spielberg vemos una serie de microuniversos y de macrouniversos).

Distinguiremos entre historia, diégesis, guión e intriga. Historia y diégesis ya han sido descritos antes, el guión es la descripción de la historia en el orden del relato y la intriga es la indicación sumaria, en el orden de la historia, del cuadro, de las relaciones y los actos que reúnen a los diferentes personajes.

Las relaciones entre relato e historia son de tres tipos: orden, duración y modo.

- El orden comprende las diferencias entre el desarrollo del relato y el de la historia.

- La duración hace mención a las relaciones entre la duración supuesta de la acción diegética y la del momento del relato que le está dedicada. Y, finalmente. . .

- El modo regula la cantidad de información dada sobre la historia por el relato. 
La principal relación entre la narración y la historia se centra en el hecho de que el discurso es un relato que sólo puede comprenderse en función de su situación de enunciación, de la que va a conservar una amplia serie de señales, mientras que la historia es un relato sin señales de enunciación, sin referencias en la que se produce.

El carácter de historia de la película de ficción, en relación con la escasa realidad del material cinematográfico en sí, le permite relanzar continuamente la atención del espectador que, en la incertidumbre de lo que seguirá a continuación, queda prendido en el movimiento de las imágenes. Aquí radica la fascinación del cine de ficción para el espectador: en su gran capacidad para convertir un discurso en historia. Spielberg, desde el principio, supo distinguir perfectamente los conceptos que provocaban dicha fascinación en el espectador. Spielberg siempre ha buscado el respaldo del público (ejercicio de mercadotecnia) incluso en sus obras más personales o las consideradas más serias.

La narración ficticia se asienta sobre los códigos narrativos, las funciones y los personajes. Casi todas las historias pueden ser reducidas a temas universales simples, pero de y en su desarrollo y circunstancias particulares esperamos como espectadores ciertas sorpresas cuando disfrutamos de una película.

Una parte de los códigos narrativos tiende a regular los avances ralentizando la solución y el final de la historia con lo que definía perfectamente la paradoja de todo relato: el avance conduce al desarrollo final, rechazándolo continuamente. El trabajo de la narración consiste en quitar importancia, en dar naturalidad a esta intriga programada a golpes por el juego de contenciones y contrarios que dan idea de progresión al azar.

Los personajes son otro de los pilares de la narración. El concepto actante de V. Propp se definía por las esferas de acción en las que ellos se desenvolvían y no por su status social o psicología. Este modelo sustancial está construido con seis términos: sujeto (tradicional figura del héroe), objeto (lo que el héroe aspira a conseguir), destinador (quien fija la misión), destinatario (recogerá el fruto), oponente (se encarga de dificultar las acciones del sujeto) y ayudante (quien le ayuda a conseguir o cumplir su misión).

Un solo personaje puede ser simultánea, eventual o alternativamente destinador y destinatario, objeto y destinador, etc... Spielberg ha sabido urdir tramas en las que sus personajes han variado poco de función de la historia. En la Trilogía de Indiana Jones, Spielberg procura crear personajes sin evolución ni psicológica ni actancial: son típicamente planos en todos los aspectos del concepto.

\subsection{La representación cinematográfica}

Lo que podemos afirmar con carácter general, es que en las películas de ficción, el personaje es el hilo conductor y posee un papel de homogeneización y de continuidad. El personaje de ficción no tiene existencia propia fuera de los rasgos físicos del actor que lo interpreta. De ahí el surgimiento del aspecto mitológico del cine de ficción narrativo: ha nacido una estrella. A partir de aquí los personajes se cortan a la medida de los actores ya consagrados.

El realismo en el cine tiene dos conceptos agazapados bajo el mismo nombre: el realismo referido a los materiales de expresión (imágenes y sonidos) y el referido a los temas de las películas. 
El concepto más interesante para nuestro estudio autorial es el de la verosimilitud, pues va a ubicar al autor frente a los verdaderos problemas de planteamiento de la obra que nos interesa. Lo verosímil hace referencia a la relación de un texto con la opinión pública, a su relación con otros textos y también al funcionamiento interno de la historia que cuenta. Los personajes de las películas (no sólo la trama o historia) han de ser tratados en torno a la verosimilitud.

Un espectador, cuando va a ver una película de Spielberg, no se plantea el mayor o menor grado de veracidad de sus películas, sino la aventura por la aventura, en los títulos que buscan el efectismo del "no va más" en acciones, acrobacias y peripecias de los héroes, con lo que la suspensión de la incredulidad es una batalla ganada ya de antemano por el director. En sus obras más densas, más profundas, Spielberg sí recrea los ambientes mostrados con la mayor carga de "realismo" posible.

\section{Spielberg: sus temas}

Spielberg ha tratado siempre temas muy similares en todas sus realizaciones:

1. "El diablo sobre ruedas": Hombre frente a imponderables, es decir, situaciones que lo superan y manejan. De ese duelo surge la superación del ser humano.

2. "Influjo de mal": El hombre se enfrenta a fuerzas espirituales que le es imposible comprender y dominar.

3. "Loca evasión": Hombre frente a imponderables que marcan su vida. Entendido el hombre como ente con sentimientos.

4. "Tiburón": Hombre frente a imponderables o situaciones que lo desbordan.

5. "Encuentros en la tercera fase": Hombre frente al cosmos, a la religión, a los misterios más profundos que lo desbordan. Es metafísica en lo que podemos considerar como un poema a la creación y a la soledad del Planeta Azul.

6. "1941": El divertimento por el divertimento, con cierta carga irónica sobre la sociedad norteamericana. Es un juego de estilo. Una distracción más para el espectador que busca evasión.

7. "Cuentos asombrosos": La búsqueda de valores superiores se trasluce por entre las líneas de este episodio.

8. "En busca del Arca perdida": La aventura por la aventura. Ciertas dosis ideológicas antinazis como encarnación del mal, pero al fin y al cabo más de lo ya visto en"1941"aunque, en esta ocasión, bajo una perspectiva menos crítica y, por supuesto, nada caricaturesca.

9. "E.T. el extraterrestre": El hombre ante sus sentimientos. Un canto a la amistad y sobre todo a la inocencia de la infancia. Este canto a la inocencia infantil será una constante en todos sus personajes de niños. 
10. "En los límites de la realidad": El episodio firmado por Spielberg es una tierna visión de otros seres débiles, como son los niños, que en este caso son los ancianos.

11."Indiana Jones y el Templo maldito": La aventura por la aventura y su constante ideológica de la lucha contra el mal.

12. "El color púrpura": Un canto a la solidaridad humana. La injusticia racial marca un tópico en Spielberg.

13."El imperio del sol": La pérdida de una inocencia que nunca se debiera malograr en el enfrentamiento brutal y traumático de un adolescente con la muerte que es, en este caso, de naturaleza violenta por la guerra.

14."Indiana Jones y la última cruzada": La aventura por la aventura, con el trasfondo ideológico de la lucha contra el mal, encarnado otra vez en los nazis. Posiblemente reduce aquí sus pretensiones en aras de la comercialidad perdida un poco en su segunda y anterior entrega.

15. "Para siempre": Es un capricho de Spielberg y su única rehechura de película anterior. Posee el valor de lo sentimental en su esencia químicamente pura. La vida del más allá, la abnegación en el regalo de la felicidad para los semejantes y seres queridos, la intervención del cielo... Es un canto más espiritual y estético que preñado de contenidos densos o pretenciosos.

16."Hook, el capitán Garfio": Película difícilmente encasillable aparte de su enfoque sobre la infancia. Se trata de no"adultizar"a los niños antes de tiempo y qué mejor metáfora que Peter Pan, el eterno niño que todos llevamos dentro.

17."Parque Jurásico": La aventura por la aventura, con un sentido teleológico del jugar a Dios más allá del bien y del mal pero sin desarrollarlo en demasía. Bien es cierto que las citas a la creación son constantes.

18. "La lista de Schindler": Otra oda a la solidaridad humana y a la eterna lucha contra el mal. Aquí sí se plantea el concepto de justicia / injusticia en todas sus facetas, incluidas las más crudas. Está basada en un personaje real.

19. "El mundo perdido": Segunda entrega, no muy acertada, del mundo de los dinosaurios. Bien es cierto que la idea de la creación y el juego de fuerzas cuya magnitud nos es imposible controlar está omnipresente por toda la obra, pero en menor intensidad y complejidad que en su primera entrega.

20. "Amistad": Vuelven los asuntos más íntimos de Spielberg a la palestra. La aberración y el desprecio por los más básicos valores que supone la esclavitud para la raza humana. El cine debe estar comprometido con la sociedad. Está basada en un hecho real. 
21. "Salvar al soldado Ryan": Su culminación técnica y narrativa como director, según toda la crítica mundial. Hay que sacar de cada persona todo lo que lleva de bueno, ya que el mundo y sus circunstancias nos plantean situaciones en las que dejar salir lo malo de nosotros mismos es lo fácil. Que nuestras vidas no hayan pasado en vano es la lectura final de una película bélica con buenos y malos.

\section{La verosimilitud}

Tratando la verosimilitud no podemos dejar de hablar del concepto género que también ofrece una serie de pautas de verosimilitud. Este efecto - género tiene una doble incidencia. Primera por la permanencia de un mismo referente diegético y por la recurrencia de escenas típicas, que permite que se consoliden de película en película. Sería, por lo tanto, crear una serie de lugares comunes o tópicos, que nos plantean los carriles o vías por donde vamos a ser capaces de aceptar y descodificar correctamente los postulados de género aplicados a una película en concreto.

Tampoco todos los géneros deben ser entendidos como de una misma categoría a la hora de crear un universo diegético propio. Este planteamiento lleva su tiempo de adaptación oral / gestual, y también la familiarización con las referencias a sociedades en las que los conceptos tradicionales se manifiestan de manera distinta. Esto nos lleva a permitirnos establecer un verosímil propio de un género en particular. Se crean una serie de leyes del género que sólo son válidas en él y alcanzan su pleno sentido de verosimilitud en ese conjunto de películas (a Indiana Jones se le permiten ciertas licencias que sólo tienen sentido en sus películas).

\subsection{Lenguaje de realidad: lenguaje cinematográfico}

El concepto de verosimilitud alcanza variaciones con el paso del tiempo, no es un corpus cerrado a cal y canto. No conviene olvidar que el cine ha estado siempre rodeado de la aureola de presentar y representar el mundo circundante y que el espectador experimenta una impresión de hallarse ante la realidad cotidiana durante la proyección de la película.

Tanto el sistema de representación icónica, el dispositivo escénico propio del cine y los fenómenos de identificación primaria y secundaria hacen que el espectador se integre en la escena representada, y se convierta, en cierto modo, en partícipe de la situación a la que asiste. Esta inclusión del espectador no le deja percibir los elementos de la representación como tales, sino como si fueran las propias cosas. Bajo esta ficción hablaremos de mayor o menor grado de verosimilitud o credibilidad de un largometraje.

\subsection{Las gramáticas cinematográficas}

Toda esta representación icónica viene determinada por la gramática cinematográfica: "la gramática cinematográfica estudia las reglas que presiden el 
arte de transmitir correctamente las ideas por una sucesión de imágenes animadas, que forman una película"․․

Las gramáticas funcionan sobre un modelo normativo de las gramáticas tradicionales del lenguaje verbal. Transmiten una estética análoga, la de la transparencia y la del realismo, y sabemos que esta estética de la transparencia, fundada en la no visibilidad de la técnica, desempeña un papel primordial en el cine.

Para poder comunicar ideas creadas y no re-creadas y contar historias, el cine hubo de elaborar toda una serie de procedimientos expresivos; el conjunto de ellos es lo que abarca el término lenguaje tal y como lo emplean dichos críticos y teóricos. El lenguaje cinematográfico está doblemente determinado por la historia y por la narratividad.

Debemos especificar que el cine, cuando es entendido como cine - lenguaje, que se limita a ser un simple vehículo de ideas o de sentimientos, oculta en sí mismo los fermentos de su propia destrucción como arte y tiende a convertirse en un medio que carece de un fin en sí mismo. Por eso debemos hacer caso a Marcel cuando afirma que: "para evitar toda ambigüedad, habría que preferir el concepto de estilo al de lenguaje." $"$

El lenguaje cinematográfico no debe ser reducido a una simple nomenclatura de procedimientos narrativos y expresivos que supongan una mera amalgama de recursos o elementos, puesto que la totalidad es más (significa más) que la suma de las partes conformantes. Esa es la base que nos permite indagar las huellas del autor a partir de la disposición de esos elementos en una secuencia única e irrepetible.

\section{Conclusiones}

Steven Spielberg cuenta con su propio sello autoral diferenciado. Un sello que se caracteriza por una sintonía inequívoca con el gusto del público en general, pero no carente por ello de inquietudes, voluntad o capacidad para llevar a cabo trabajos con un compromiso intelectual de más hondo calado. Incluso sus trabajos comerciales comparten con las cintas más introspectivas y personales una voluntad de "brújula moral" que no pierde peso por envolverse en un vibrante ritmo visual y unos golpes de efecto sonoros tendentes a lo memorable.

El modo en que se emplean los recursos narrativos del medio para arrancar la ovación popular a través de la historia de aventuras, o para conducir las conciencias en un drama histórico-bélico, nos lleva a señalar que Spielberg cuenta con una reserva de recursos cuya periodicidad y familiaridad han terminado por desembocar en un todo que el público y la crítica pueden reconocer. Retomando el esquema de S. Chatman: Spielberg cuenta con acciones históricas reconocibles y pautables,

GARCÍA JIMÉNEZ, Jesús (1993): Narrativa audiovisual. Editorial Cátedra. Madrid.

$\gamma$

MARTIN, Marcel (1955): Le langage cinématographique. Editorial Du Cerf. París. 
sobre todo en sus filmes más comerciales. Sus personajes y escenarios son así mismo muy personales, en la acepción de fácilmente reconocibles como obra suya. En el ejemplo tomado de la trilogía de Indiana Jones cuentan, quizá, con una mayor tridimensionalidad, que sirve para indicarnos la importancia de unos y otros personajes como elementos dentro de cada película. Si desea hacer que el público empatice con la causa de un protagonista, el público sabrá que es así. Las temáticas, el modo en que trata las gentes, los objetos, y los referentes con los que trabaja son constantes en la trilogía de Indiana Jones y más allá. Los postulados temáticos son sencillos, dotados de la profundidad justa y con unos referentes morales occidentales fácilmente aceptables por gran parte del mundo globalizado que constituye su público.

Discursivamente, la estructura de la transmisión narrativa se mantiene constante en la trilogía de forma casi milimétrica; calculando de forma exhaustiva los efectos a general en cada momento. Su pulso autorial se hace más intenso como director conforme más seria es la película o el momento fílmico en sí. Jugando con el nivel de atención del espectador a voluntad. Los elementos sonoros y visuales tienden marcadamente a la repetición de los aspectos relevantes y/o significativos. Casi siempre como elementos de auxilio psicológico para situaciones o personajes. Lo que redunda en un efecto mayor para sus películas "ligeras" o de aventuras, al combinar para ello música, sonido, iluminación y otros elementos expresivos. Aquellas cintas acreedoras a un mayor respeto tienen una intención mucho menos efectista, desfigurando su estilema si el espectador casual se mantiene solo en lo superficial de la expresión artística. Todos los elementos citados, sin embargo, se mantienen inviolables en la capa subyacente con la que estas películas apelan al Óscar.

\section{Bibliografía}

BELLOUR, Raymond (1980): "Á bâtons rompus", en Theorie du film. Obra colectiva. Editorial Albatros. París.

BELLOUR, Raymond 81974): L'analyse du film. Editorial Galilée. París.

BUNGE, Mario (1980): Epistemología. Editorial Ariel. Barcelona

FERRATER MORA, José Et Al. (1979): Diccionario de filosofía. Editorial Suramericana. Buenos Aires.

GARCÍA JIMÉNEZ, Jesús (1993): Narrativa audiovisual. Editorial Cátedra. Madrid.

MARTIN, Marcel (1955): Le langage cinématographique. Editorial Du Cerf. París. 